\title{
Landslide Risk Analysis in Kelud Volcano, East Java, Indonesia
}

\author{
Syamsul Bachri*, Sumarmi, Listyo Yudha Irawan, Sugeng Utaya, Lela Wahyu Ning Tyas, Farizki Dwitri Nurdiansyah, \\ Alif Erfika Nurjanah, Rahmat Wirawan, Akhmad Amri Adillah and Denny Setia Purnama \\ ${ }^{1}$ Department of Geography, State University of Malang, Jl. Semarang 05, Malang 65145, Indonesia
}

Received: 2021-04-27

Accepted: 2021-11-29

\section{Keywords:}

Modelling;

hydrology;

discharge;

watershed;

electric power

Correspondent email: sardi@ung.ac.id

\begin{abstract}
Pandansari village became one of the villages that has frequent landslide events in the period 20092015 compared with the surrounding area in Malang regency. The purpose of this study was to determine the level of landslide risk located within an active volcano. To enhance the comprehensive analysis of landslide disasters, we used a risk concept in this study. The landslide risk analysis was based on 3 determinants, namely hazards, community vulnerability, and regional capacity. The data collections were conducted using observation and documentation for landslide hazards and interviews as well as Focus Group Discussion (FGD) for vulnerability and capacity aspects. The interviewed were applied for community and local government of Pandansari village. The recorded interviews were transcribed and analyzed according to recurrent themes in the answers. Findings from field investigation were then confronted with previous existing concepts of human exposure to natural hazards. Furthermore, the landslide hazard data were analyzed using spatial analysis tools, including GIS scoring, weighting, and overlaying weighted sum. The results showed the level of landslide risk has different values depending on the risk parameter, community vulnerability, and regional capacity. The level of landslide risk was divided into three levels, namely high with an area of 557.71 ha, moderate with 774.49 ha, and low with 1118.77 ha. Each of the risk factors, vulnerability, and capacity, has its characteristics in influencing the landslide risk in Pandansari Village. In relation to landslide disaster management, the risk analysis gives comprehensive input reaching good management practice in Pandansari village.
\end{abstract}

@2021 by the authors. Licensee Indonesian Journal of Geography Indonesia.

This article is an open access article distributed under the terms and conditions of the Creative Commons Attribution(CC BY NC) licensehttps://creativecommons.org/licenses/by-nc/4.0/.

\section{Introduction}

Indonesia is a country with the highest number of volcanoes in the world, namely 129 active volcanoes or around $15 \%$ of all volcanoes worldwide (Abidin et. al., 20017). One of the active volcanoes in Indonesia is Kelud Volcano in East Java Province. Administratively, it is located in 3 regencies: Blitar, Kediri, and Malang. The last increase in Kelud Volcano eruption activity occurred on February 14, 2014, which produced volcanic material of $>200 \times 10^{6} \mathrm{~m}^{3}$ (Blake \& GNS Science., 2015).

The amount of eruption material of a volcano may trigger other disasters (Nurdiansyah, 2017). The eruption of Kelud Volcano has a direct and indirect impact on the physical, social, and economic conditions of the surrounding community (Bachri, 2017). One of the secondary hazards (continued) that might follow the volcano eruption is a landslide disaster (Huppert \& Dade, 1998; Keys, 1998).

A landslide is one of the geological hazards that may cause injury, loss of life, and loss to the community. Landslides are defined as the movement of soil, rocks, and organic matter, that follows the direction of gravity (Nadim et al. 2006; Highland \& Bobrowsky, 2008), which are controlled by geomorphological and geological factors (Van Westen et al., 2011) and may be triggered by various control factors, such as rainfall, earthquakes, volcanic activity, changes in groundwater, and anthropogenic activity (Ermini et al., 2005; Catani et al., 2005; Ercanoglu, 2002; Highland \& Bobrowsky, 2008).
Ngantang District in Malang Regency has a relatively higher frequency of landslides when compared with other districts in Malang Regency (Profile Book of Malang Regency BPBD in Ahdi (2015).

Pandansari Village in Ngantang District was the worst affected village of the Kelud Volcano eruption in 2014, especially due to the sand and volcanic ash fall (Wardhana, Garri Martha Kusuma, 2014; Lestari, et.al., 2014). Pandansari village was one of the villages that have the potential for landslides. Almost all hamlets in Pandansari Village have a land carrying capacity condition and slopes of more than 45 ${ }^{\circ}$, this caused the area to be prone to landslides. The magnitude of the potential/likelihood of a landslide disaster has given rise to the need to make a comprehensive effort on disaster risk through an analysis of landslides risk in this region to minimize the impact of losses from the disaster (Chiu., 2015). Since the direction of landslide disaster is currently more in technical part (viz. mapping), this research try to make a comprehensive study to capture landslide hazards in Pandasari village through risk concept analysis. Three-component such as hazard, vulnerability, and capacity analysis were applied in this study.

This research is located in Pandansari Village, which is one of the very impacted areas because of the Mount Kelud eruption in February 2014. Administratively Pandansari Village is part of Ngantang District, Malang Regency, East Java. Pandansari Village consists of seven "Dusun", namely 
Plumbang, Bales, Munjung, Sambirejo/ Kutut, Wonorejo/ Pait, and Sedawun, and one land ownership managed by Perhutani (Fig. 1).

Pandansari Village is located in "Kawasan Rawan Bencana" (KRB) 2 and 1, which approximately has a radius from Mount Kelud between 6-7 kilometers. In February 2014 because of Mount Kelud Eruption, this event caused enormous damage to settlement, public facilities, and agricultural land. Figure 2 shows that many houses were severely damaged because of material that ejected from Mount Kelud Eruption.
The material ejected from Mount Kelud eruption in 2014 reached more than $200 \times 10^{6} \mathrm{~m}^{3}$ (Bachri et al, 2019). According to Balitkabi Litbang Pertanian, the thickness of material eruption that covered the Pandansari Village area reached between 25 - 40 centimeters. Because of the huge of material from Mount Kelud eruption that covered Pandansari Village, it will trigger another geophysical hazard, especially landslide. . In the future, eruption material that covers the entire area of Pandansari Village will be a source of landslide material. Therefore, the research related to landslide risk assessment is important to carry out because it will be the basis for disaster risk reduction.

Table 1. Disaster Prone Areas in Malang Regency

\begin{tabular}{ll}
\hline \multicolumn{1}{c}{ Natural Disasters } & \multicolumn{1}{c}{ Regional } \\
\hline \hline Landslide & $\begin{array}{l}\text { Ngantang, Kasembon, Pujon, Dampit, Tirtoyudo, Ampelgading, Donomulya, Wajak, Poncokusu- } \\
\text { mo, Jabung }\end{array}$ \\
\hline Flood & Singosari, Tirtoyudo, Dampit, Sumawe, Bantur, Amplegading \\
Drought & Kalipare, Pagak, Sumawe, Singosari, Poncokusumo, Donomulyo,Sumberpucung, Bantur, Gedangan \\
Tsunami & $\begin{array}{l}\text { Donomulyo, Bantur, Gedangan, Sumawe, Tirtoyudo, Ampelgading } \\
\text { Storm } \\
\text { Volcano }\end{array}$ \\
& $\begin{array}{l}\text { Kalang Regency } \\
\text { Kosembon, Ngantang, Pawang, Jabung }\end{array}$ \\
\hline
\end{tabular}

Source : Profile Book of Malang Regency BPBD in Ahdi (2015).
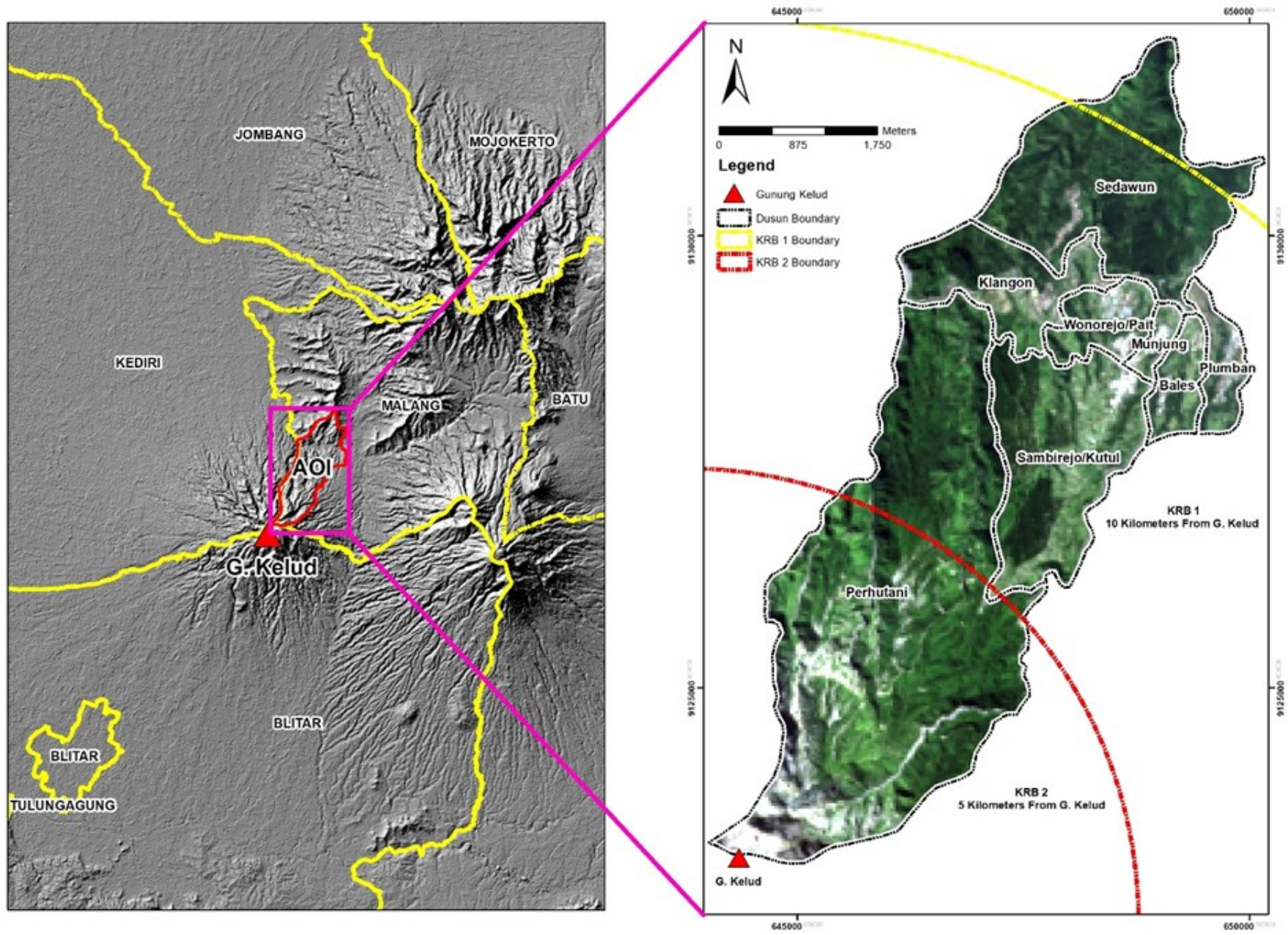

Figure 1. Pandansari Village, Ngantang District for This Study Area 
Table 1. Disaster Prone Areas in Malang Regency

\begin{tabular}{ll}
\hline \multicolumn{1}{c}{ Natural Disasters } & \multicolumn{1}{c}{ Regional } \\
\hline Landslide & $\begin{array}{l}\text { Ngantang, Kasembon, Pujon, Dampit, Tirtoyudo, Ampelgading, Donomulya, Wajak, } \\
\text { Poncokusumo, Jabung } \\
\text { Flood }\end{array}$ \\
Singosari, Tirtoyudo, Dampit, Sumawe, Bantur, Amplegading \\
Kalipare, Pagak, Sumawe, Singosari, Poncokusumo, Donomulyo,Sumberpucung, Bantur, \\
Gedangan
\end{tabular}
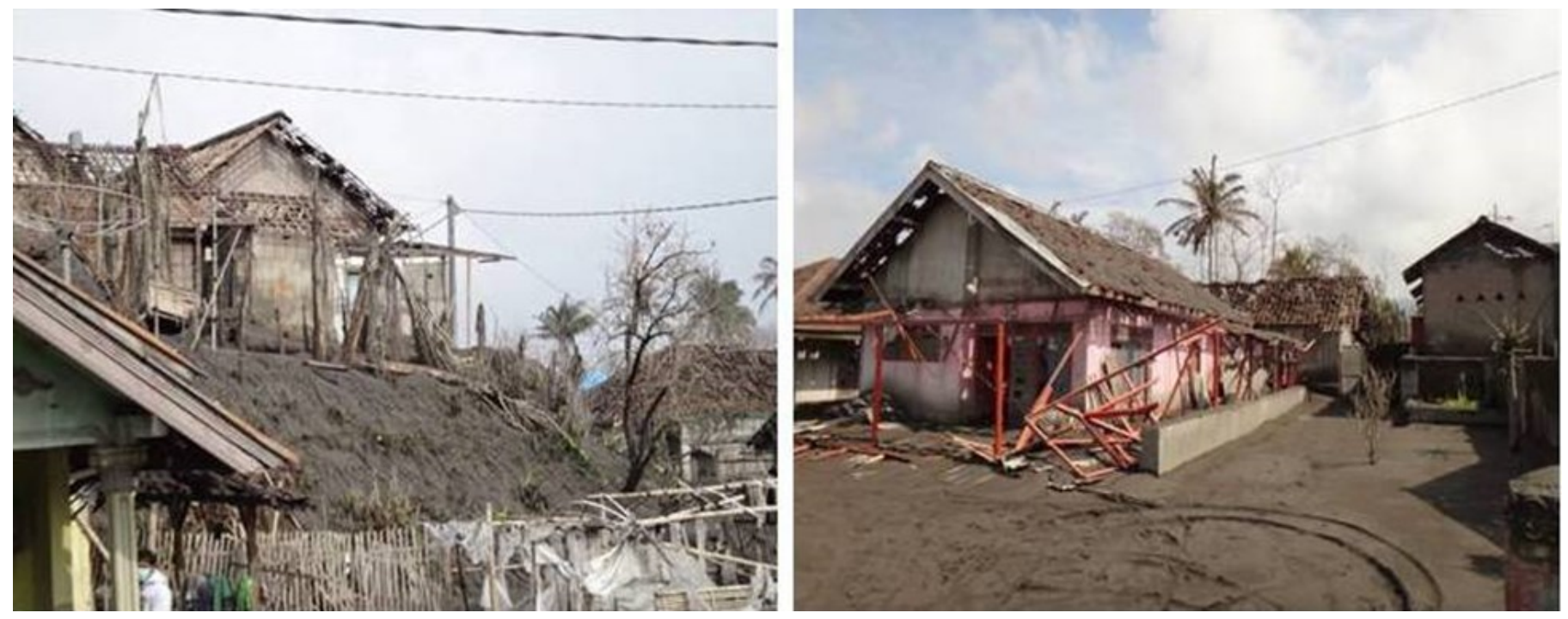

Figure 2. The Damage to Settlement in Pandansari Village After Mount Kelud Eruption in 2014 (Image by Balitkabi Litbang Pertanian)

The material ejected from Mount Kelud eruption in 2014 reached more than $200 \times 10^{6} \mathrm{~m}^{3}$ (Bachri et al, 2019). According to Balitkabi Litbang Pertanian, the thickness of material eruption that covered the Pandansari Village area reached between 25 - 40 centimeters. Because of the huge of material from Mount Kelud eruption that covered Pandansari Village, it will trigger another geophysical hazard, especially landslide. . In the future, eruption material that covers the entire area of Pandansari Village will be a source of landslide material. Therefore, the research related to landslide risk assessment is important to carry out because it will be the basis for disaster risk reduction.

\section{Methods}

This study referred to two data collection processes, namely primary and secondary. Primary data collection was carried out through field observations, interviews, and Focus Group Discussions (FGD) to determine the level of hazard and capacity of the area in Pandansari Village in facing the landslides disaster. Whereas, secondary data was in the form of data collected from legislation, books, websites, and journals that are relevant to determine the level of vulnerability of the community in Pandansari Village, Ngantang District.
Factors that play a role in determining hazards and assessing disaster risks in the study area are the threat/danger factors, community vulnerability factors, and regional capacity factors (vig. Tabel 2). Hazard factor assessment is an important part of disaster risk analysis (Ayala., 2001, (Fell et al., 2008, Van Westen et al., 2008),).

The assessment of the hazard factor in this study was arranged based on the parameters that caused landslides to occur based on the research conducted by Nurdiansyah (2017) using the Fuzzy-AHP method. The community vulnerability factor was based on the Regulation of the Head of the National Disaster Management Agency No. 02 of 201, covering physical, social, economic, and environmental parameters.

The factor of capacity/capability of the region was prepared based on the Regulation of the Head of the National Disaster Management Agency Number 03 of 2012, covering the rules and institutions of disaster management; early warning and disaster risk assessment; disaster education; reduction of basic risk factors; and development of preparedness on all lines.

The classification of landslide risk level in Pandansari Village, Ngantang District was divided into 3 classes, namely high, moderate, and low, see Table 3. 


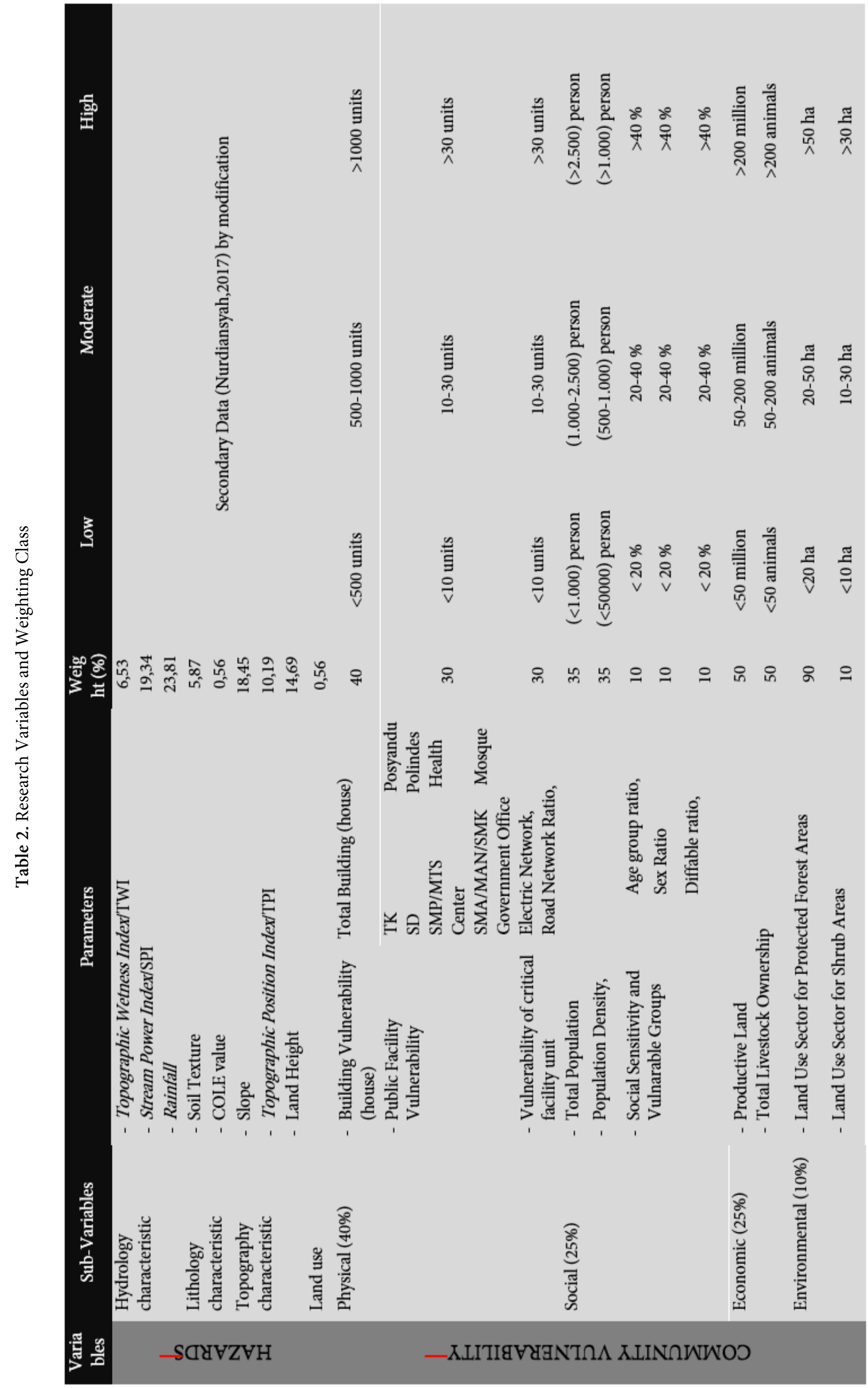




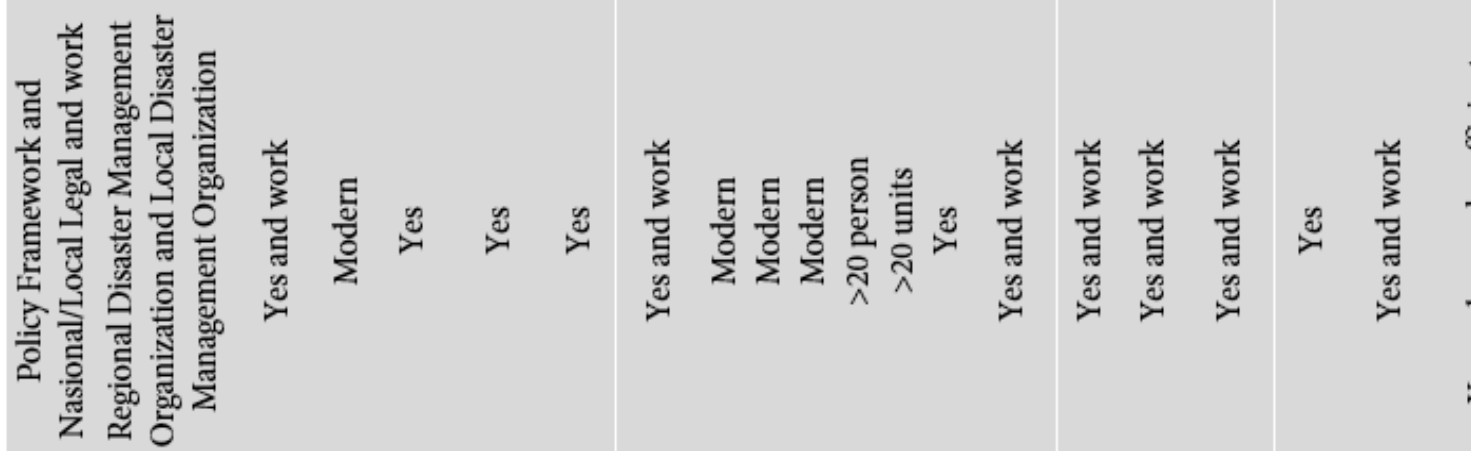

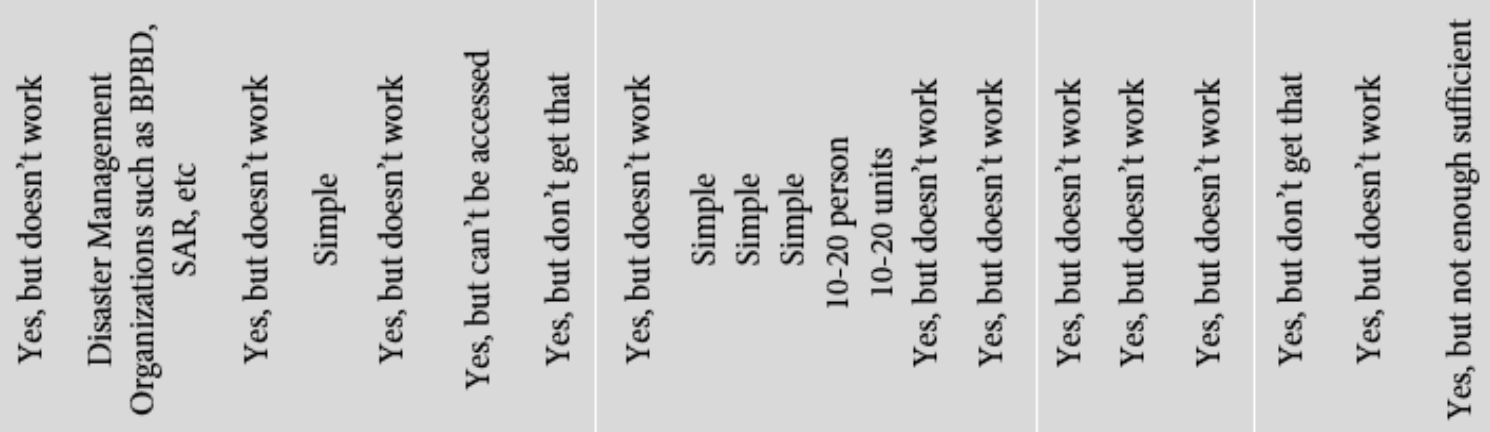

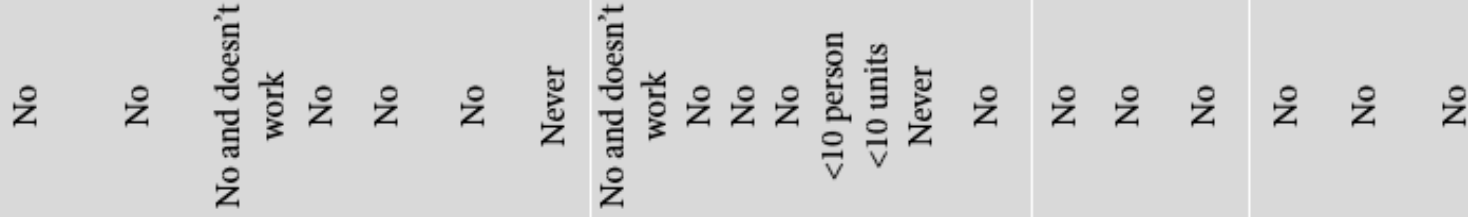

0
0
0
0
0
0
0
00
3
0
0
0
0
0
0
0
0
0
0
0
0
0
0
0
0
0
0
0
0
0
0
0
0
0

กิ

สิ

กิ

突

赜
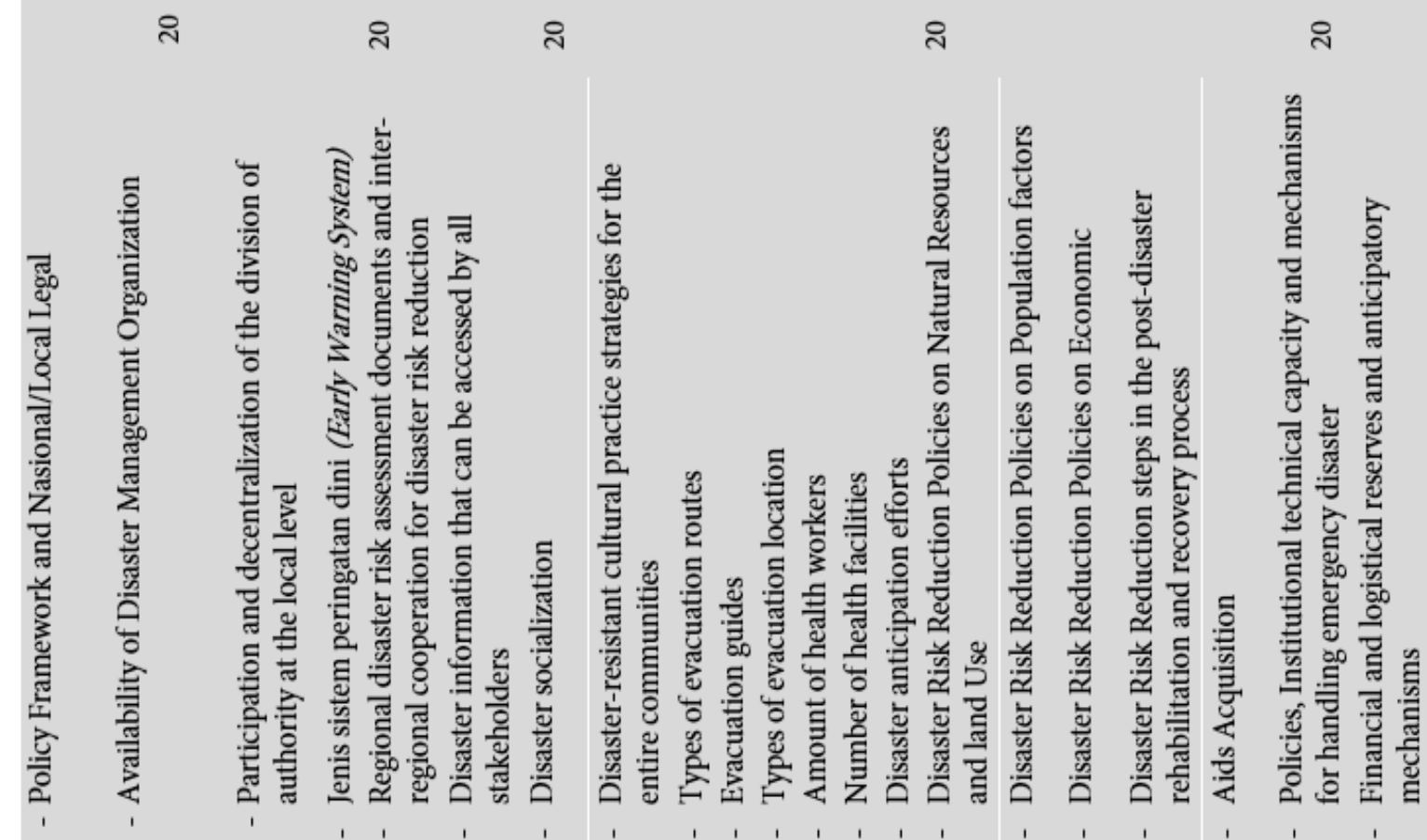

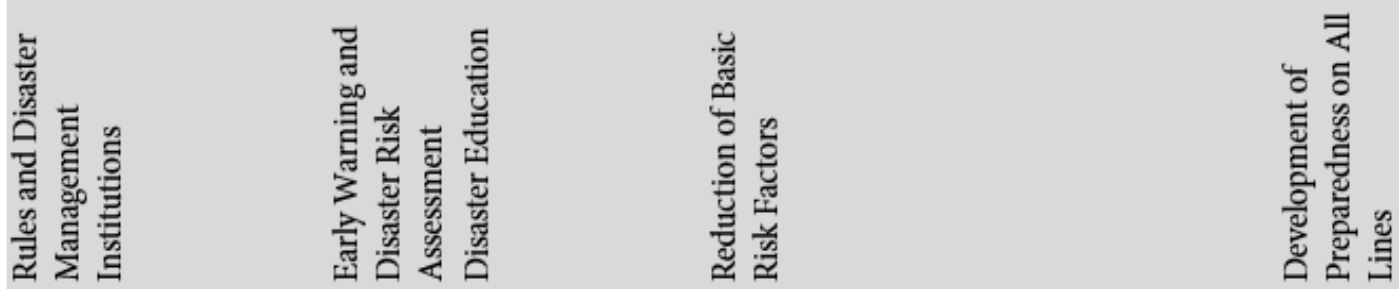


Table 3. Landslide Hazard Level

\begin{tabular}{cccc}
\hline Interval & Criteria & Class & Score \\
\hline $24-30$ & High Hazard Level & 1 & 30 \\
$17-23$ & Moderate Hazard Level & 2 & 20 \\
$10-16$ & Low Hazard Level & 3 & 10 \\
\hline
\end{tabular}

Source : Data Analysis, 2018

The total vulnerability score in Pandansari Village, Ngantang District, was calculated using the formula below:

Total Vulnerability $=$

$\{40$ (social vulnerability) +25 (physical vulnerability) + 25 (economic vulnerability) +10 (environmental vulnerability) $\}$

The classification of the total vulnerability level in Pandansari Village, Ngantang Subdistrict was divided into high, moderate, low as see Table 4.

The determination of the disaster capacity level in Pandansari Village, Ngantang District, was carried out using the following calculation:

\section{Capacity Level $=$}

$\{20$ (disaster management rules and institutions) +20 (early warning and disaster risk assessment) +20 (disaster education $)+20$ (basic risk factors reduction) +20 (development of preparedness on all lines)\}

The classification of the total capacity level of Pandansari Village in Ngantang District was divided into high, moderate, and low as see Table 5 .

The data on landslide risk factors, community vulnerability, and area capacity were then analyzed using Geographic Information System (GIS) by utilizing the weighting technique, scoring, and overlay weighted sum as the determinant of the landslide risk level. The landslide risk disaster assessment could be done using the following approach:

\section{Disaster Risk = \\ Hazard $\times$ Vulnerability Capacity}

Table 4. Total Vulnerability Level

\begin{tabular}{llll}
\hline \multirow{2}{*}{ Interval } & Criteria & Class & Score \\
\hline $24-30$ & High Vulnerability Level & 1 & 30 \\
$17-23$ & Moderate Vulnerability Level & 2 & 20 \\
$10-16$ & Low Vulnerability Level & 3 & 10 \\
\hline
\end{tabular}

Source : Data Analysis, 2018

Table 5. Total Capacity Level

\begin{tabular}{cccc}
\hline Interval & Criteria & Class & Score \\
\hline $24-30$ & High Capacity Level & 1 & 30 \\
$17-23$ & Moderate Capacity Level & 2 & 20 \\
$10-16$ & Low Capacity Level & 3 & 10 \\
\hline
\end{tabular}

The classification of landslide risk disaster in Pandansari Village, Ngantang District, was divided into three level of high, moderate, and low, by using interval class calculation as follows:

Interval Class of Disaster Risk $=\frac{\text { Total High Score }- \text { Total Lowest Score }}{\text { Total Class }}$

$$
\text { Interval Class }=\frac{39,75-6,12}{3}=\frac{33,63}{3}=11,21
$$

Table 6. Classification of Landslide Risk Disaster

\begin{tabular}{cccc}
\hline Interval & Criteria & Class & Score \\
\hline $24-30$ & High Level & 1 & 30 \\
$17-23$ & Moderate Level & 2 & 20 \\
$10-16$ & Low Level & 3 & 10 \\
\hline
\end{tabular}

Source: Data Analysis, 2018

The analysis process using GIS produced a low, moderate, and high level of zones in each factor. The following step was the process of visualizing data in the form of maps. The utilization of GIS technology was a standard tool for spatial production and presentation of disaster risk information. The research scheme carried out in this study can be seen in Figure 3.

\section{Result and Discussion}

Landslide Hazard Analysis

A hazard is a phenomenon carrying the potential to cause loss of life or injury, property damage, social and economic disturbances, or environmental degradation. This event has the possibility of occurring within a certain period, area, and intensity (UN-ISDR, 2004). Based on the results of the analysis, 3 categories of landslide hazards was identified in each hamlet and land ownership in Pandansari Village, Ngantang District, namely landslide hazard in the low category with an area of 56.22 ha, moderate category with an area of 638.11 ha, and high category with an area of 1768.92 ha. The mapping of landslide susceptibility/ hazard provides the basis for predicting landslide events in the form of landslide susceptibility/ hazard zoning.

The Distribution Landslide Analysis for Each Class Hazard Category

Low category of landslides hazards in Pandansari Village has an area of 56.22 ha or around $2.28 \%$ of the total study area. The hamlet with the most extensive low landslide hazard category was Klangon Hamlet with an area of 32.69 ha. 


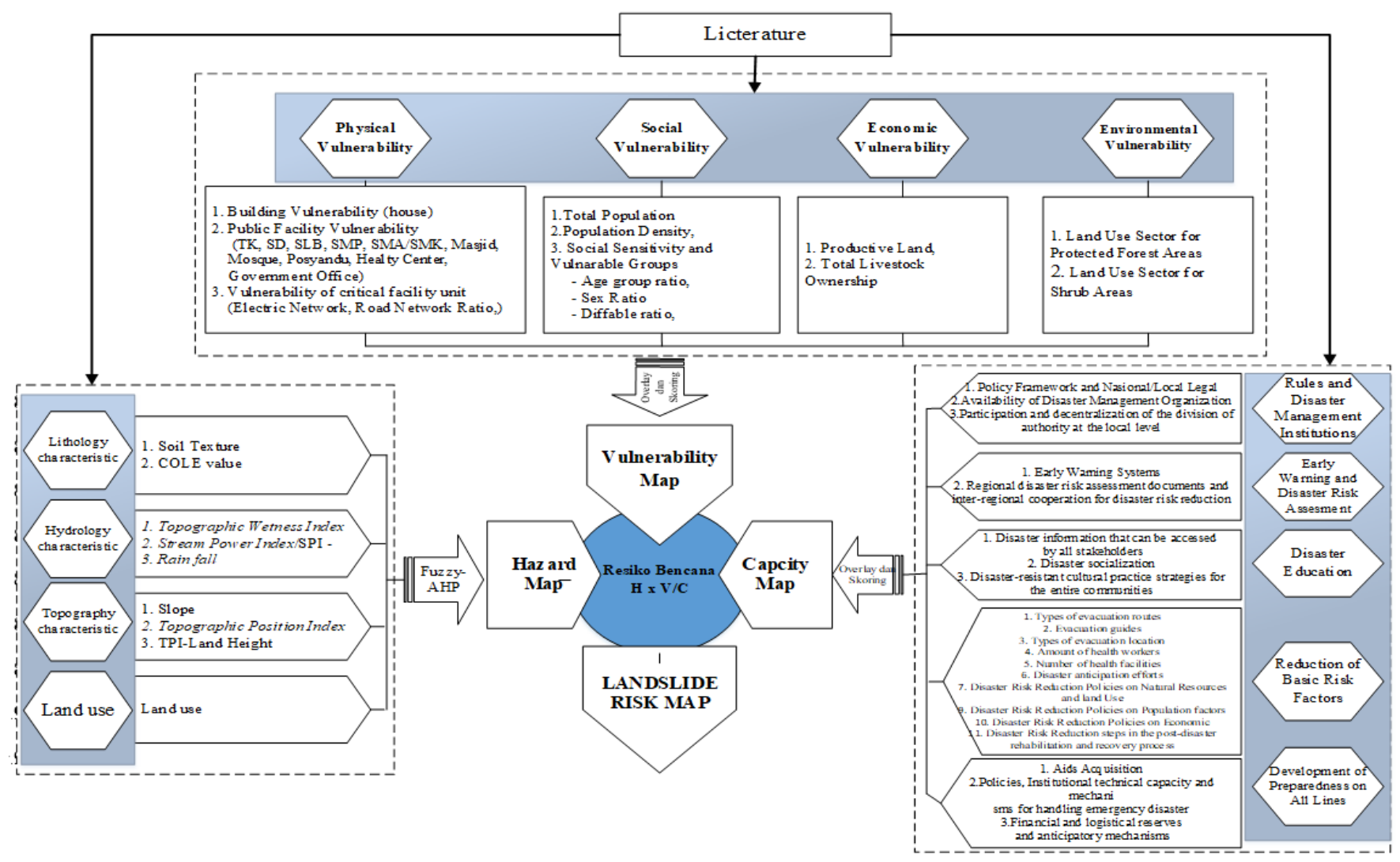

Figure 3. Work Flow the Research
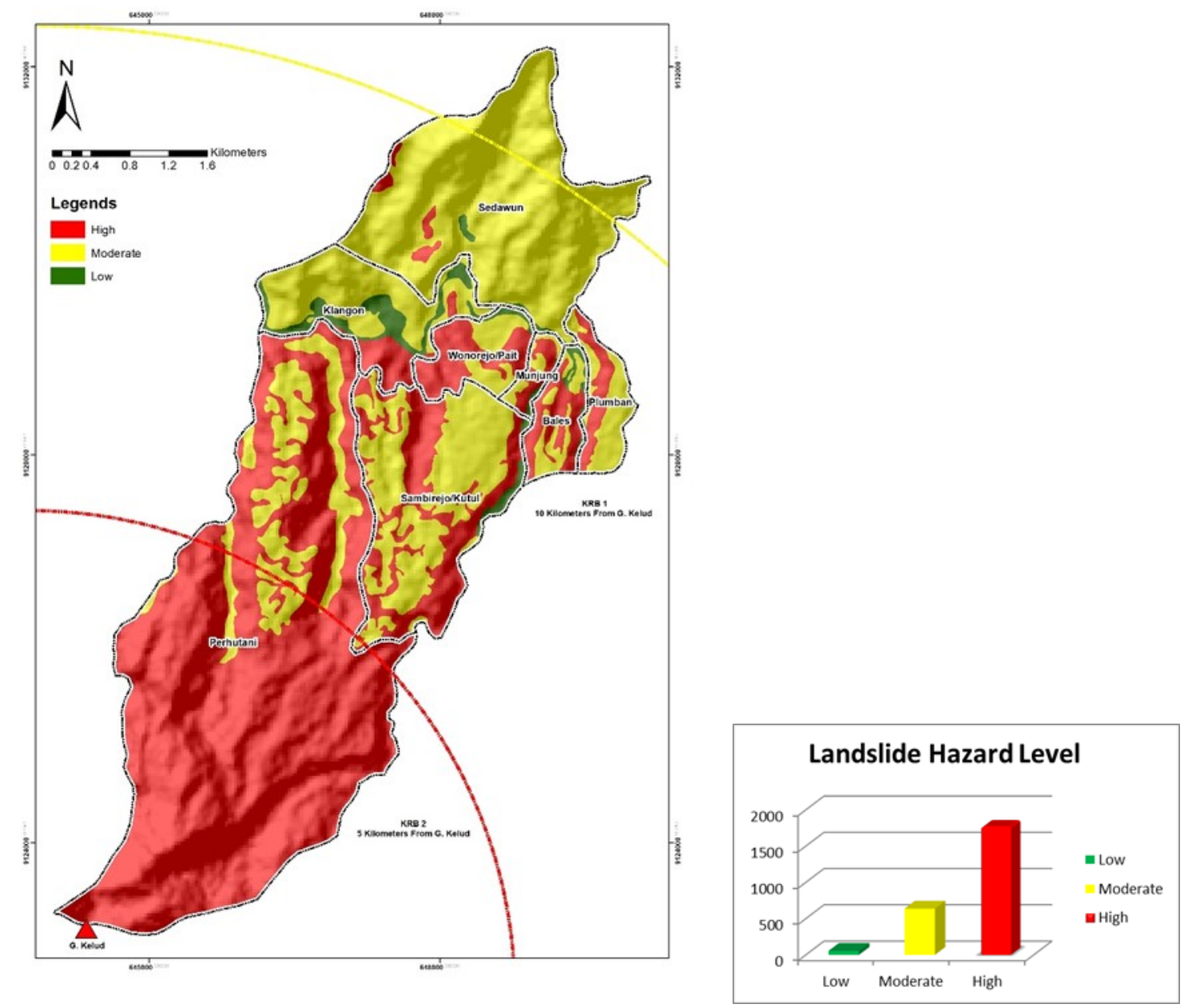

Figure 4. Maps and Diagrams of Landslide Hazard in Pandansari Village, Ngantang District 
The land characteristics developed in this class were having a flat slope, tending to be around the watershed, and land use was dominated by rice fields. The moderate category of landslide hazard in Pandansari Village has an area of 638.11 ha or about $25.90 \%$ of the total study area. Based on figure 5, the hamlet which the widest landslide hazard class was Sambirejo Hamlet with an area of 176.05 ha. Land characteristics developed in this class were a sloping slope, andesite rock, volcanic breccias, tuff breccias, tuff and andesite deposits, regosol and lithosol, and land use in the form of rice fields and plantation.

The agricultural land use such as horticultural plantations and rice fields are areas that were most affected by the eruption of Mount Kelud in 2014. This area has a potential for landslides because the agricultural area in Pandansari Village is located in an area with a slope of more than $15 \%$. The rice fields are not strong enough to bind the soil and cause the soil to be saturated with water, making it easy for landslides to occur (Karnawati, 2003). In figure 3 shows how the material eruption damaged to a horticultural plantation in Pandansari Village and shows the thickness of the material that covered this agriculture land use.

The high category of landslide hazard in Pandansari Village has an area of 1768.92 ha or about $71.81 \%$ of the total research area. The land belonging to Perhutani was the widest landslide hazard category compared to the others, with an area of 1124.74 ha.

Land characteristics developed in this class were steep to very steep slopes, sedimentary rocks, volcanic breccias, tuff, and andesite lava, regosol, reddish-brown lithosol, and latosol, and land use which are mostly forest and shrubs. Karnawati (2001) explained that slope topography is a very important factor in the process of landslides. Steep and steep slopes or cliffs may increase the driving force so that the landslide occurrences of a landslide are higher. This situation is influenced by the geomorphological conditions of the

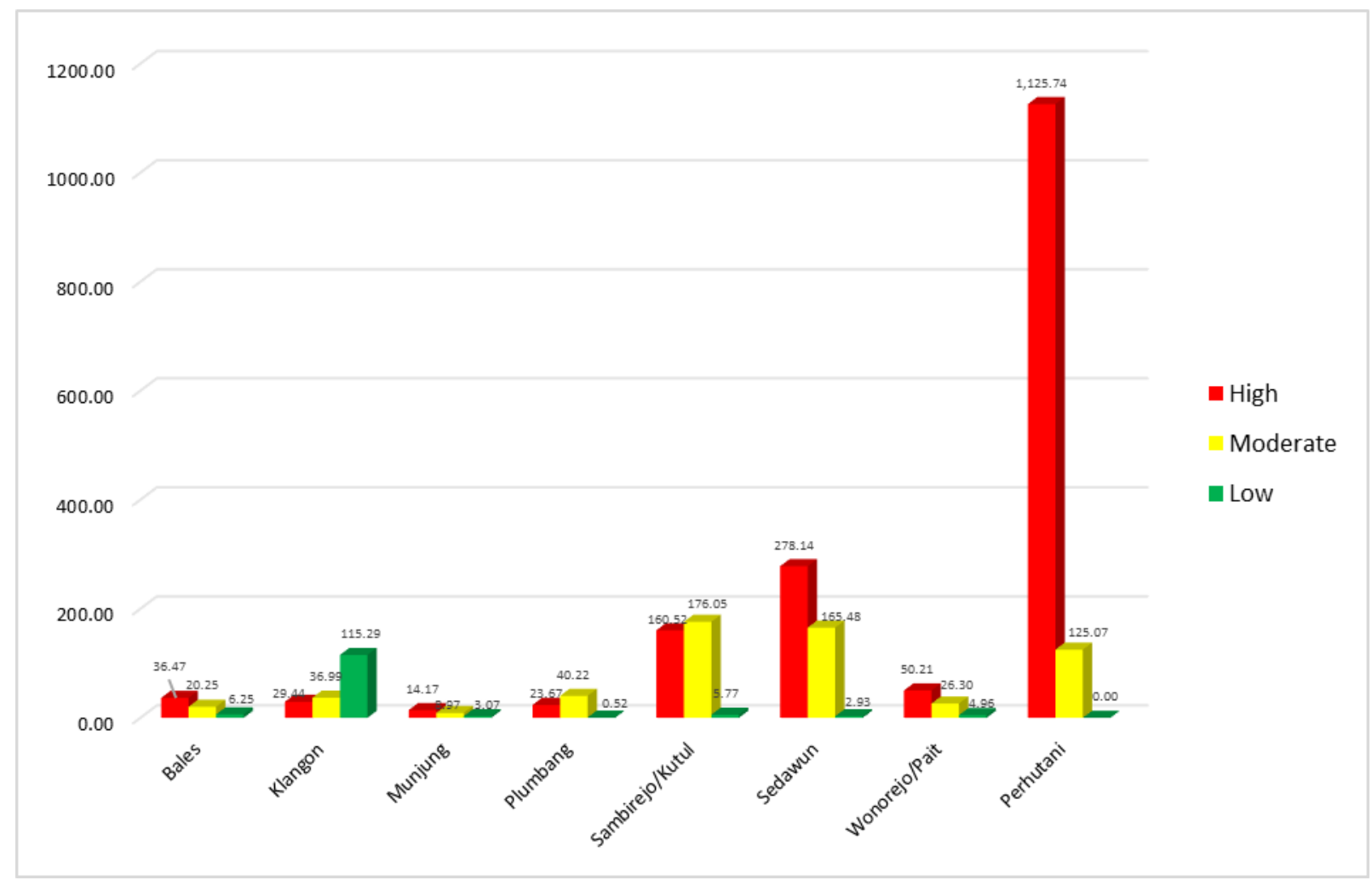

Figure 5. The Category of Landslide Hazard Diagram in Pandansari Village, Ngantang District
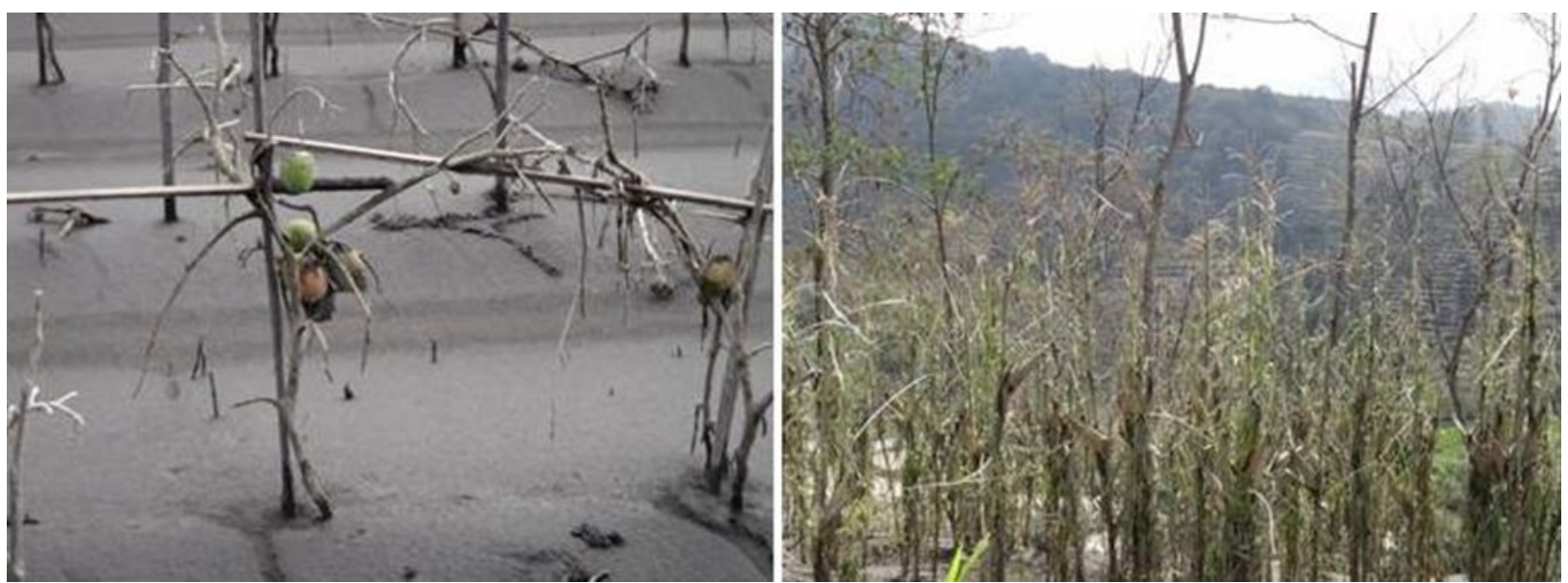

Figure 6. Horticultural Plantations (Tomato and Corn) Damaged by Mount Kelud Eruption in February 2014 
research area, which is located in a volcanic region. In addition to the dominance of the middle slopes to the top of the volcano, the nature of the soil structure is dominated by the slickenside on the moderate slope triggering factor for landslides.

The degradation of land resources quality due to the increasingly complex demand for land tenure or land processing results in a decrease in land carrying capacity (Moniaga, 2011). A lot of types of human activities, ranging from land-use changes to the scarps construction without regard to the slope stability (Surono, 2003), further aggravate the environmental conditions that cause the possibility of a landslide hazard to increase.

Landslide distribution/inventory map has a role to detect, delineate, and describe the spatial distribution of areas with the potential for landslides (Guzzeti et al., 1990; Corominas, 2013) and understand changes in the appearance of the earth's surface and become the basis for the risk and vulnerability assessment of landslide hazard (Nurdiansyah, 2017).

\section{The Vulnerability Aspect of Landslide Hazard}

Vulnerability conditions in the study area are influenced by physical and socio-economic conditions (Westgate and O'Keefe, 1976; Maskey, 1993). In this research, we used the vulnerability factors, such as physical, social, economic and environmental vulnerabilities (UNPD, 2004; UN-ISDR, 2004; Blaikie et al., 1994; Pelling, 2003). The results of the parameters used in determining aspects of community vulnerability can be seen in some of the images see Figure 7.

\section{Area Capacity Aspect}

The area capacity factor in this study has been regulated in the Regulation of the Head of BNPB Number 03 year 2012, concerning the guidelines for assessing regional capacity in disaster management. Regional capacity aspects in implementing disaster management are important parameters for determining success for disaster risk reduction. The capacity data/regional capability related to the management of landslide disasters in Pandansari Village, Ngantang District, were acquired using interview methods and Focus Group Discussion (FGD). FGD activities are a means of obtaining information, opinions, and ideas from all participants on a topic that is accompanied by explanations (Krueger, 1988).

There were two classes of regional capacity in each hamlet and land ownership in Pandansari Village, Ngantang District, namely the high capacity class with an area of 1199.09 ha and

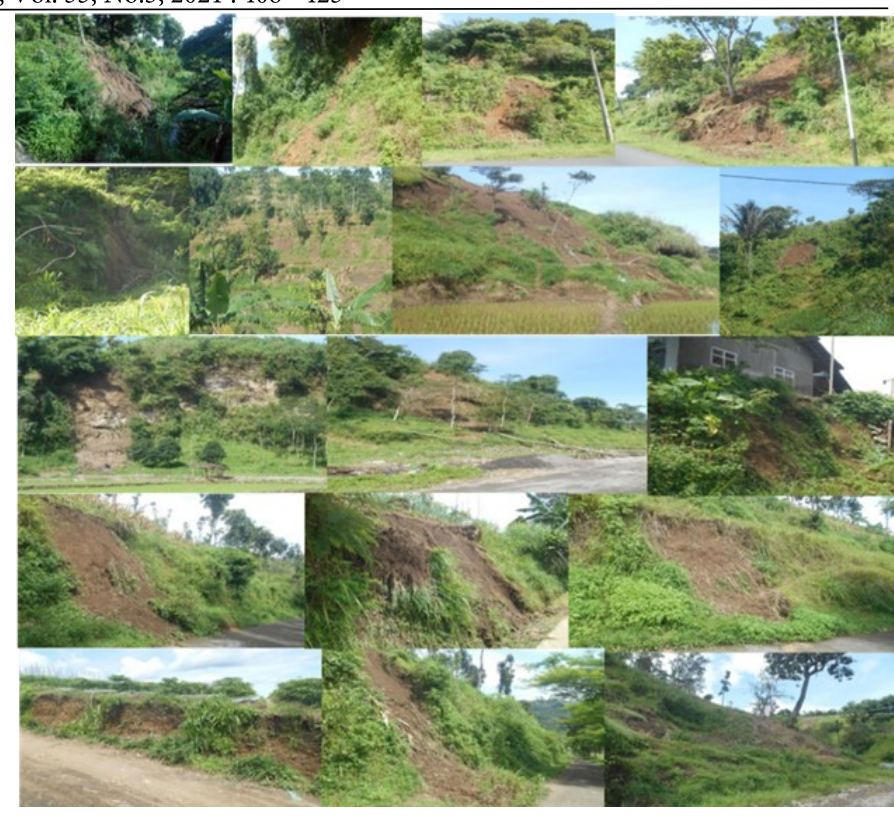

Figure 7. Landslide Hazard in Pandansari Village, Ngantang District

the low capacity class with an area of 1258.88 ha. Factors influencing the high capacity class were the high level of rules and institutional parameters, early warning and disaster risk assessment, disaster education, and reduction of basic risk factors. While the preparedness development factor in all lines was in the medium level category.

The community capability in Pandansari Village to prepare themselves, to prevent and overcome disasters was done by completing infrastructure, regulations, completeness of the communication system, evacuation of health facilities, training, socialization, organizational completeness, the community capability to reduce, prevent and manage continuing disasters with related parties. This was in accordance with the statement (Anderson \& Woodrow, 1989 in Paripurno 2001) that the resources, skills, knowledge, the ability of the community, organizational capabilities, and the attitude to act in this case are necessary to face disasters. Ideas and practices carried out by the community were the evidence of the communities capability to deal with disasters.

\section{The Risk of Landslide Hazard in Pandansari Village, Ngantang District}

One of the benefits of calculating disaster risk is as the material in formulating preparedness plans and strategic actions in disaster mitigation. In fact, risk analysis is an important aspect that needs to be considered in spatial

Table 7. Total Vulnerability Score in Pandansari Village

\begin{tabular}{|c|c|c|c|c|c|c|}
\hline \multirow{2}{*}{ Land Ownership } & \multicolumn{5}{|c|}{ Vulnerability Score } & \multirow{2}{*}{$\begin{array}{c}\text { Total } \\
\text { Vulnerability } \\
\text { Level }\end{array}$} \\
\hline & Physical & Social & Economic & Environmental & TOTAL & \\
\hline Dusun Plumbang & 20 & 20 & 30 & 10 & 22,4 & Moderate \\
\hline Dusun Bales & 10 & 10 & 20 & 20 & 16,2 & Moderate \\
\hline Dusun Munjung & 10 & 20 & 20 & 10 & 16,7 & Moderate \\
\hline Dusun Sambirejo & 20 & 10 & 30 & 30 & 18,35 & Moderate \\
\hline Dusun Wonorejo & 10 & 10 & 20 & 20 & 16,2 & Moderate \\
\hline Dusun Klangon & 10 & 10 & 20 & 30 & 15,7 & Low \\
\hline Dusun Sedawun & 20 & 10 & 20 & 30 & 17,1 & Moderate \\
\hline Perhutani & 10 & 10 & 10 & 30 & 13,25 & Low \\
\hline
\end{tabular}



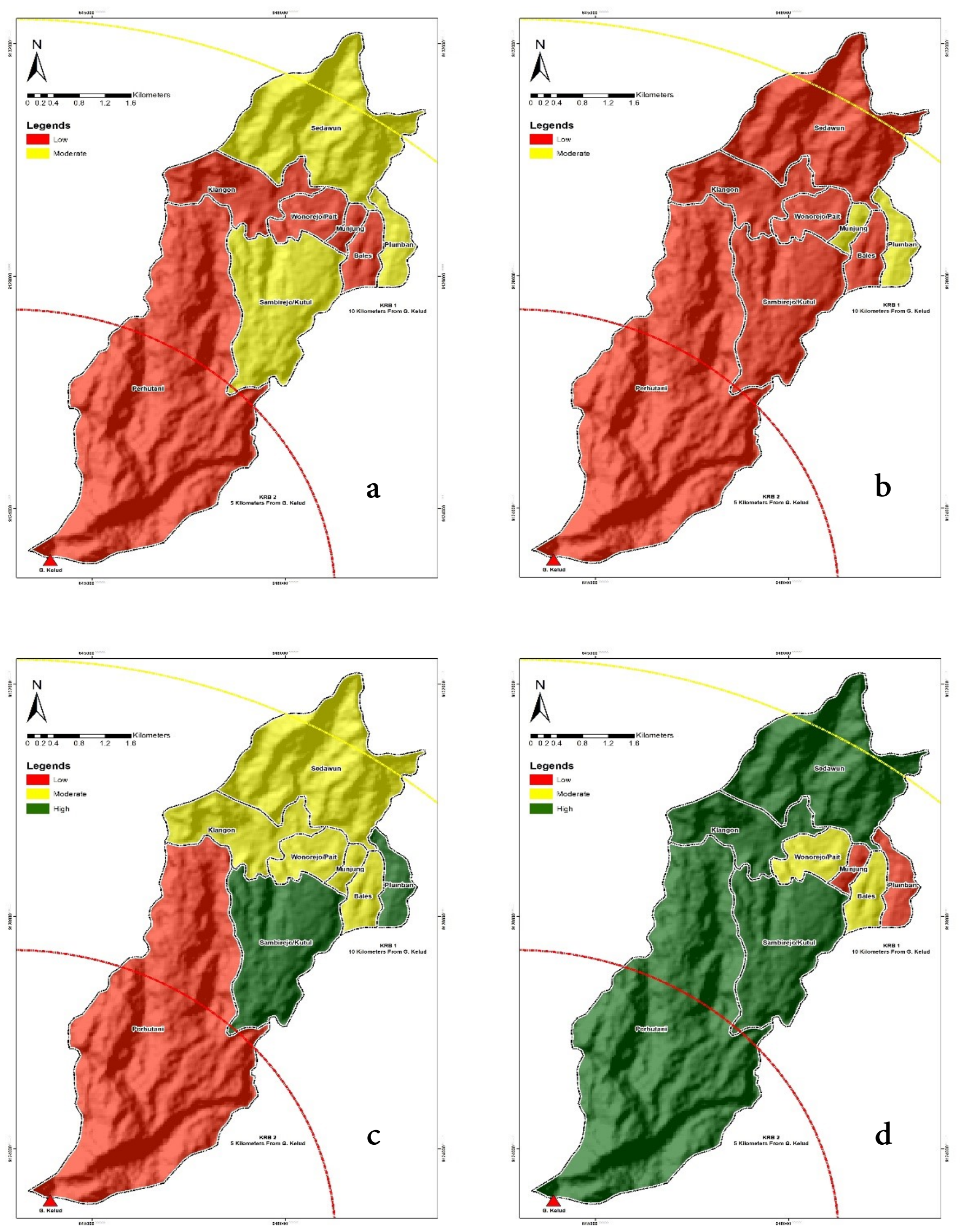

Figure 8. Determining Parameters of Vulnerability Level: a. Physical, b. Social, c. Economic, d. Environment. 


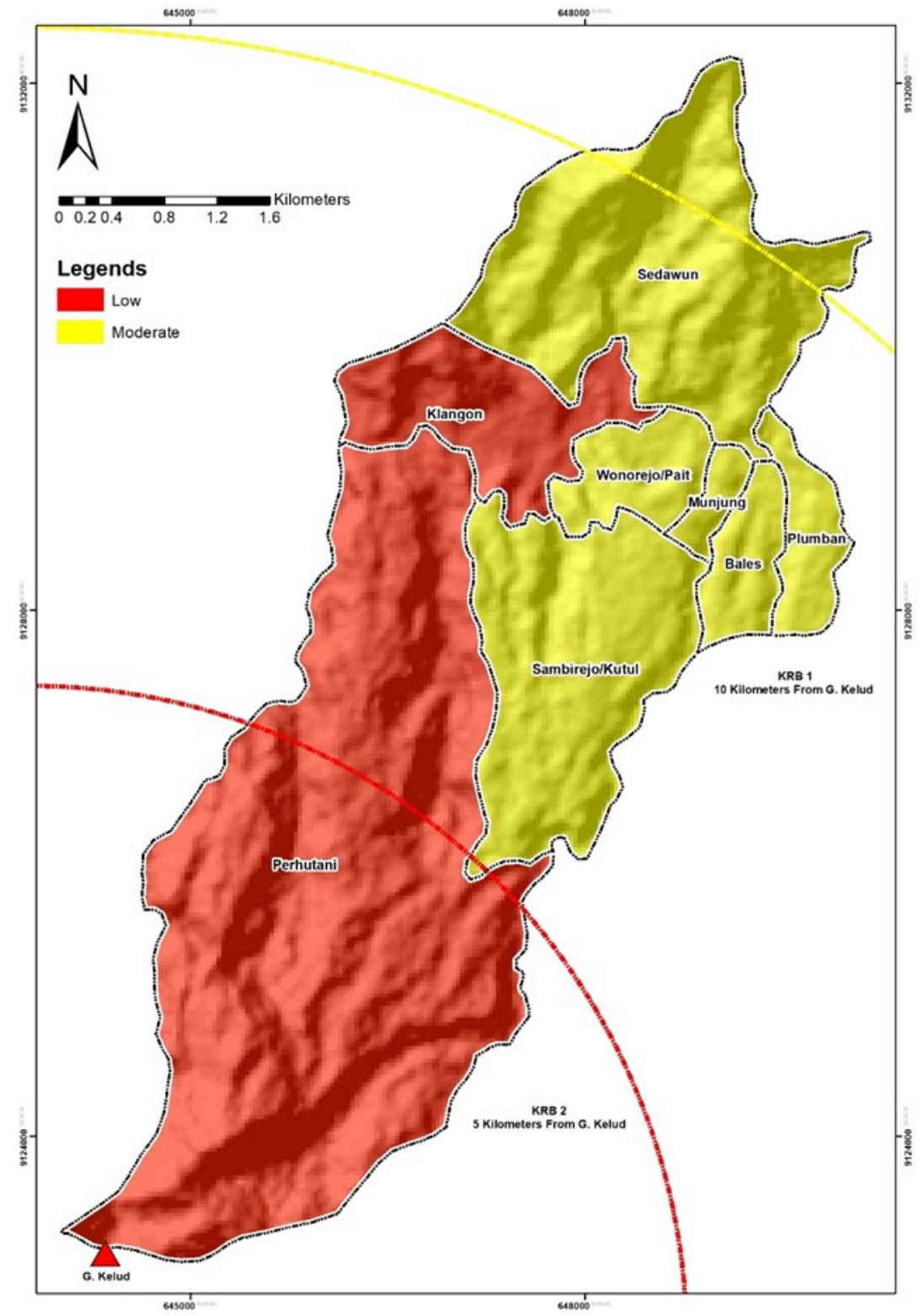

Figure 9. Maps and Diagrams of Vulnerability Level in Pandansari Village, Ngantang District
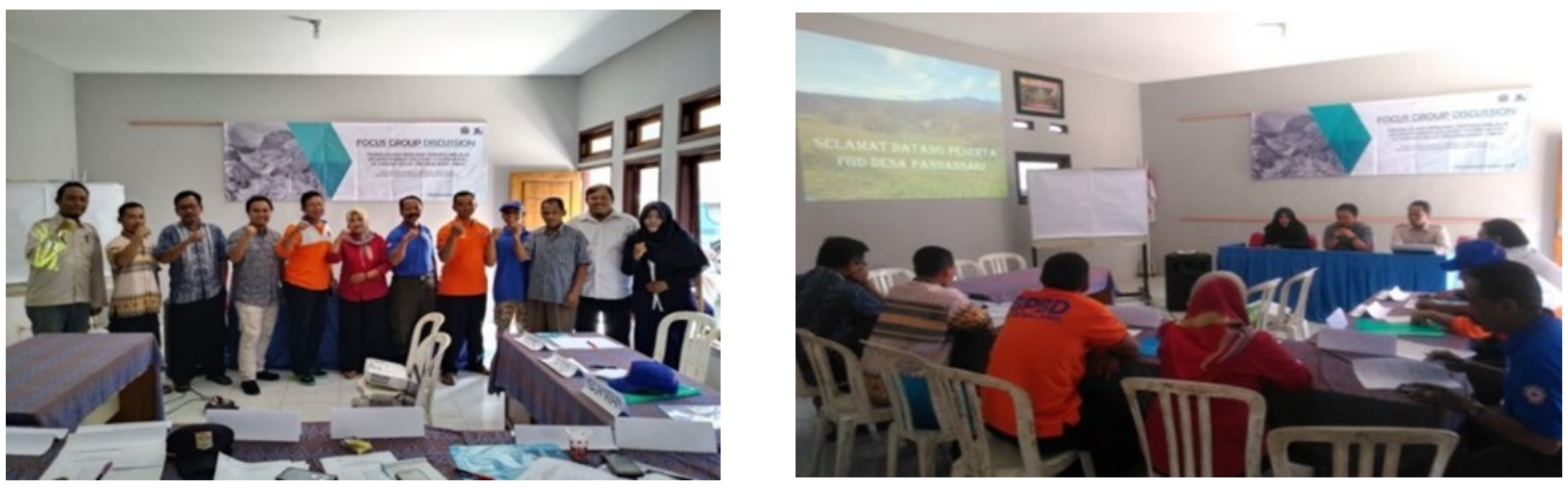

Figure 10. Focus Group Discussion (FGD) in Pandansari Village, Ngantang District 
Table 8. Total Capacity Level in Pandansari Village, Ngantang District

\begin{tabular}{|c|c|c|c|c|c|c|c|}
\hline \multirow[b]{2}{*}{$\begin{array}{l}\text { Land Owner- } \\
\text { ship }\end{array}$} & \multicolumn{6}{|c|}{ Capacity Score } & \multirow[b]{2}{*}{$\begin{array}{c}\text { Total } \\
\text { Capacity } \\
\text { Level }\end{array}$} \\
\hline & $\begin{array}{c}\text { Rules and } \\
\text { Disaster } \\
\text { Management } \\
\text { Institutions }\end{array}$ & $\begin{array}{c}\text { Early } \\
\text { Warning a } \\
\text { nd Disaster } \\
\text { Risk } \\
\text { Assessmen } \\
\mathrm{t} \\
\end{array}$ & $\begin{array}{l}\text { Disaster } \\
\text { Education }\end{array}$ & $\begin{array}{l}\text { Reduction of } \\
\text { Basic Risk } \\
\text { Factors }\end{array}$ & $\begin{array}{l}\text { Development of } \\
\text { Preparedness on } \\
\text { All Lines }\end{array}$ & TOTAL & \\
\hline $\begin{array}{c}\text { Dusun } \\
\text { Plumbang }\end{array}$ & 26,66 & 30 & 30 & 26 & 20 & 26,53 & High \\
\hline Dusun Bales & 26,66 & 25 & 30 & 24 & 26,66 & 26,46 & High \\
\hline $\begin{array}{l}\text { Dusun } \\
\text { Munjung }\end{array}$ & 26,66 & 30 & 30 & 22 & 20 & 25,73 & High \\
\hline $\begin{array}{c}\text { Dusun } \\
\text { Sambirejo }\end{array}$ & 26,66 & 25 & 26,66 & 23 & 20 & 24,26 & High \\
\hline $\begin{array}{c}\text { Dusun } \\
\text { Wonorejo }\end{array}$ & 26,66 & 25 & 30 & 22 & 26,66 & 26,06 & High \\
\hline $\begin{array}{l}\text { Dusun } \\
\text { Klangon }\end{array}$ & 26,66 & 30 & 30 & 24 & 13,33 & 24,8 & High \\
\hline $\begin{array}{l}\text { Dusun } \\
\text { Sedawun }\end{array}$ & 26,66 & 30 & 30 & 24 & 26,66 & 27,46 & High \\
\hline Perhutani & 10 & 10 & 10 & 10 & 10 & 10 & Low \\
\hline
\end{tabular}

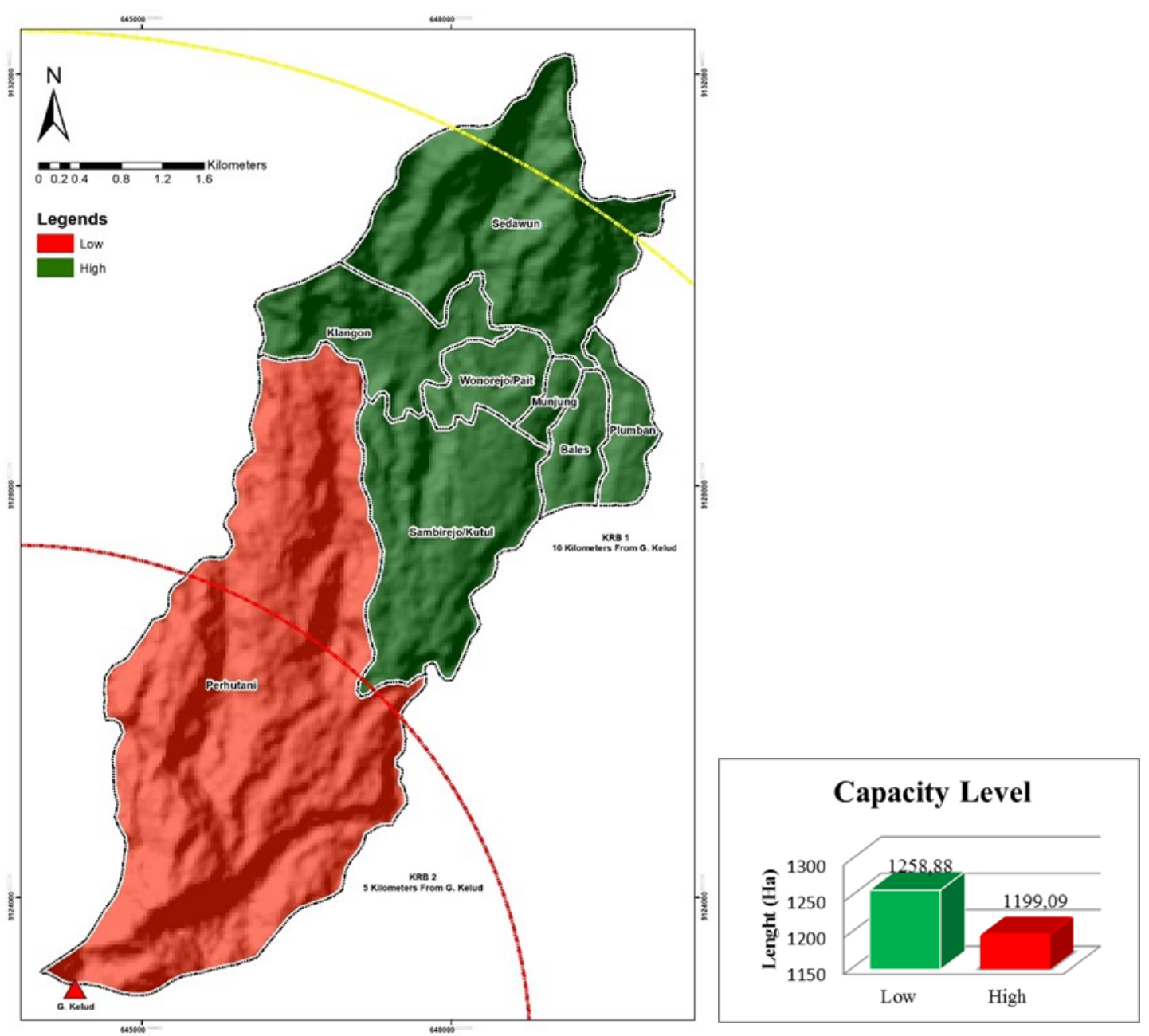

Figure 11. Maps and Diagrams of Capacity Level in Pandansari Village, Ngantang District 


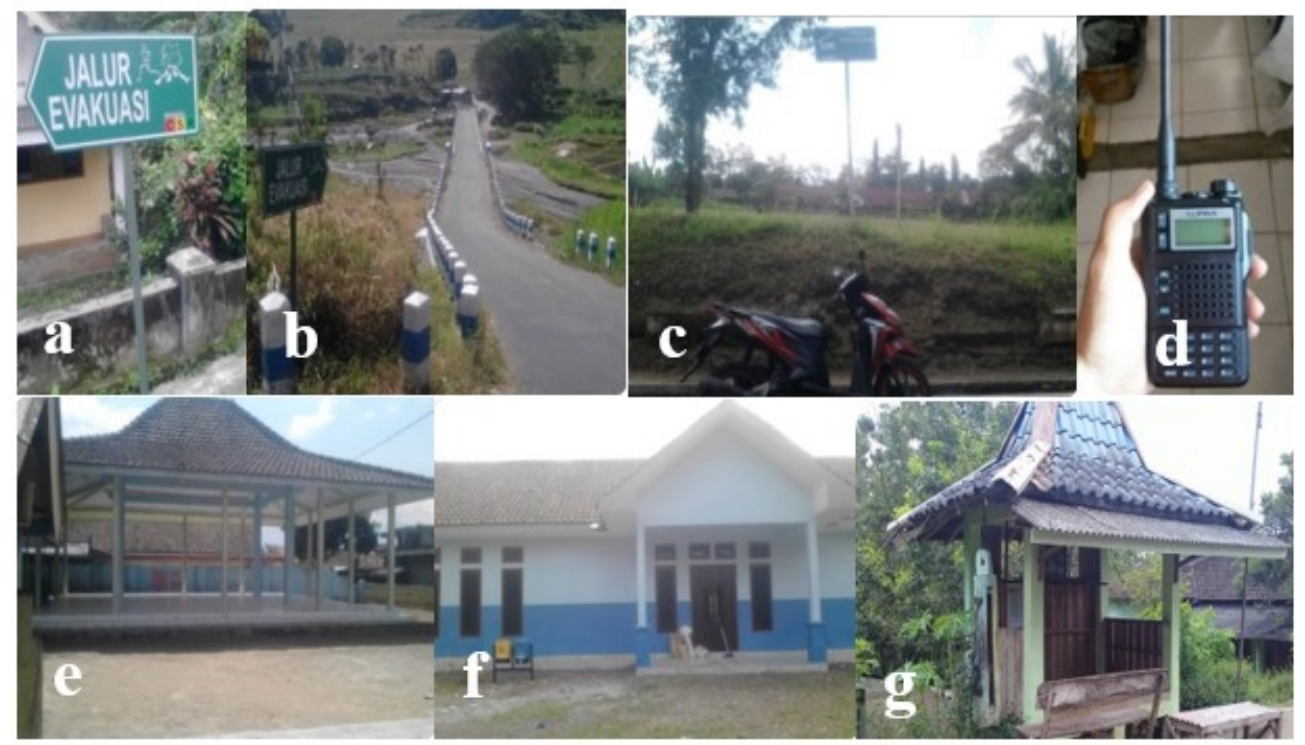

Figure 12. Types of evacuation facilities and health facilities in Pandansari Village, Ngantang

District: a. Evacuation guides, b. Jembatan penyebrangan, c. Evacuation location (field),

d.Handly Talkie, e. Evacuation location (government office), f. Health center, g. Kentongan

Table 9. Landslide Hazard Risk Level In Pandansari Village, Ngantang District

\begin{tabular}{ccccc}
\hline \multirow{2}{*}{ Land Ownership } & \multicolumn{3}{c}{ The landslide hazard risk level (ha) } & \multirow{2}{*}{ Total Luas (ha) } \\
\cline { 2 - 4 } & Low & Moderate & High & 63,40 \\
Dusun Plumbang & 39,82 & 23,58 & 0,00 & 62,42 \\
Dusun Bales & 26,29 & 36,13 & 0,00 & 26,21 \\
Dusun Munjung & 12,04 & 14,17 & 0,00 & 339,15 \\
Dusun Sambirejo & 180,63 & 158,52 & 0,00 & 81,48 \\
Dusun Wonorejo & 31,26 & 50,21 & 0,00 & 180,19 \\
Dusun Klangon & 99,23 & 80,96 & 0,00 & 445,23 \\
Dusun Sedawun & 168,42 & 276,81 & 0,00 & 1243,78 \\
Perhutani & 0,00 & 125,01 & 1118,77 & \\
\hline
\end{tabular}

planning (Sudibyakto, 124: 2011). Determination of landslides risk category in this study was influenced by the variables of hazard, vulnerability, and capacity. Those variables were processed using Geographic Information System (GIS) technology so that the results of the landslides risk level in Pandansari Village could be estimated spatially.

The landslide hazard risk level in Pandansari Village, Ngantang District, was divided into 3 classes, namely low, moderate, and high. Each hamlet and land ownership in Pandansari Village has different width of landslide risk level.

The factor most influencing disaster risk level was the landslides risk factor. That was suspected due to the high category landslide hazard was the most dominating factor compared to other landslide risks in Pandansari Village. However, community vulnerability and regional capacity also have an influence in terms of increasing and reducing the risk level of landslides.

Risk and community vulnerability factors may increase the disaster risk, while capacity factor leads to the opposite. Therefore, there is a need for improvement and management efforts related to potential disaster and potential damage that may occur due to landslides hazard. Cooperation is needed from all parties involved in the efforts to increase disaster capacity and management in the areas prone to landslides. Stakeholder involvement has been widely recognized to support good disaster risk communication strategy decisions, so as to provide an overview and input for further decision making in terms of disaster management (Nadim, 2009).

Preparation of the Landslide Disaster Risk Assessment Matrix

The preparation of the landslide risk matrix in this study was based on the calculation of landslide hazard, community vulnerability, and area capacity of the Pandansari Village. The matrix preparation started with the assessment of initial landslide risk (disaster threat), involving landslide hazards parameters and community vulnerability.The estimation was carried out by connecting the two-parameter values in the matrix and the color of the meeting point symbolized the initial landslide risk (disaster threat) before the capacity or area capacity.

After the results of the initial landslide risk (disaster threat) were obtained, the values were then combined with the capacity factor to determine the risk level of the final landslide disaster. 

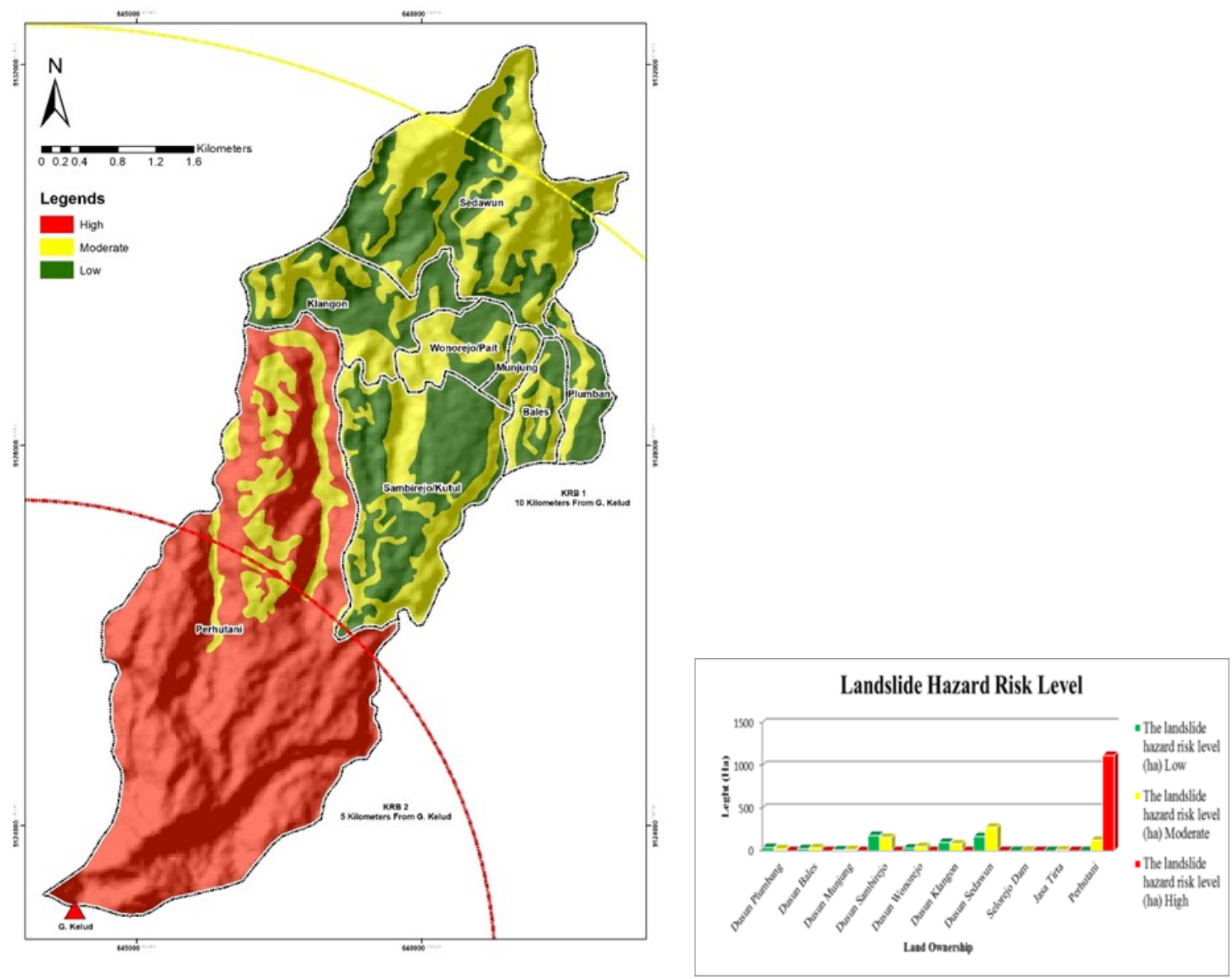

Figure 13. Landslide hazard risk level in Pandansari Village, Ngantang District

Table 10. Landslide Disaster Risk Assessment Matrix (disaster threat)

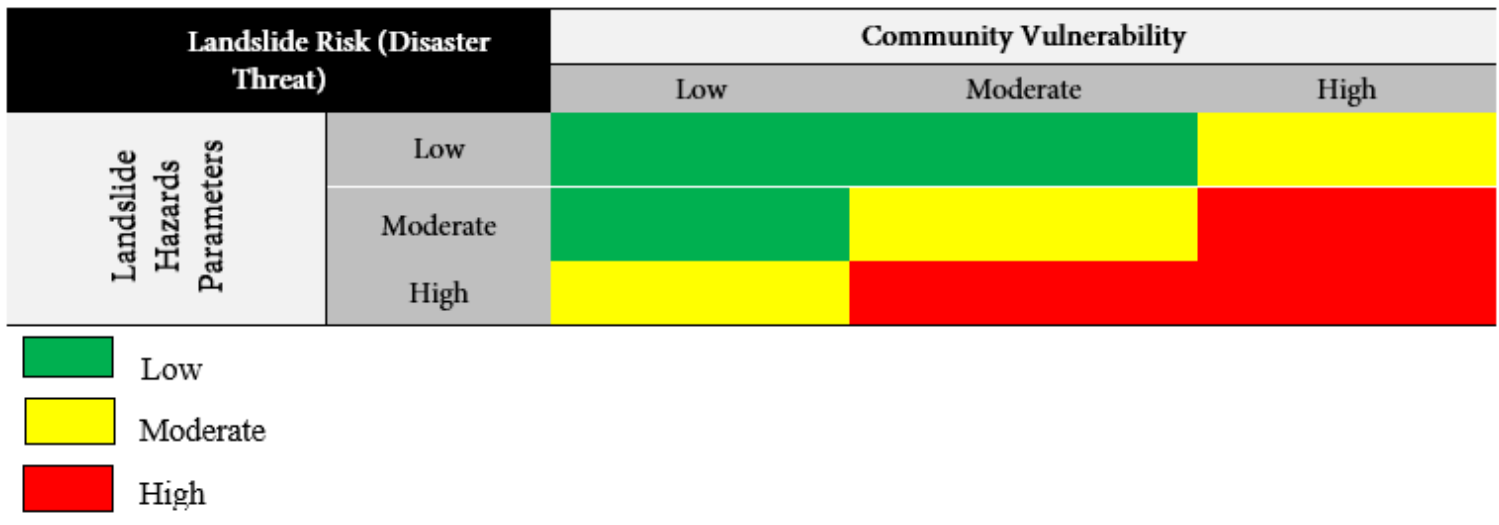

Table 11. Final Landslide Disaster Risk Assessment Matrix

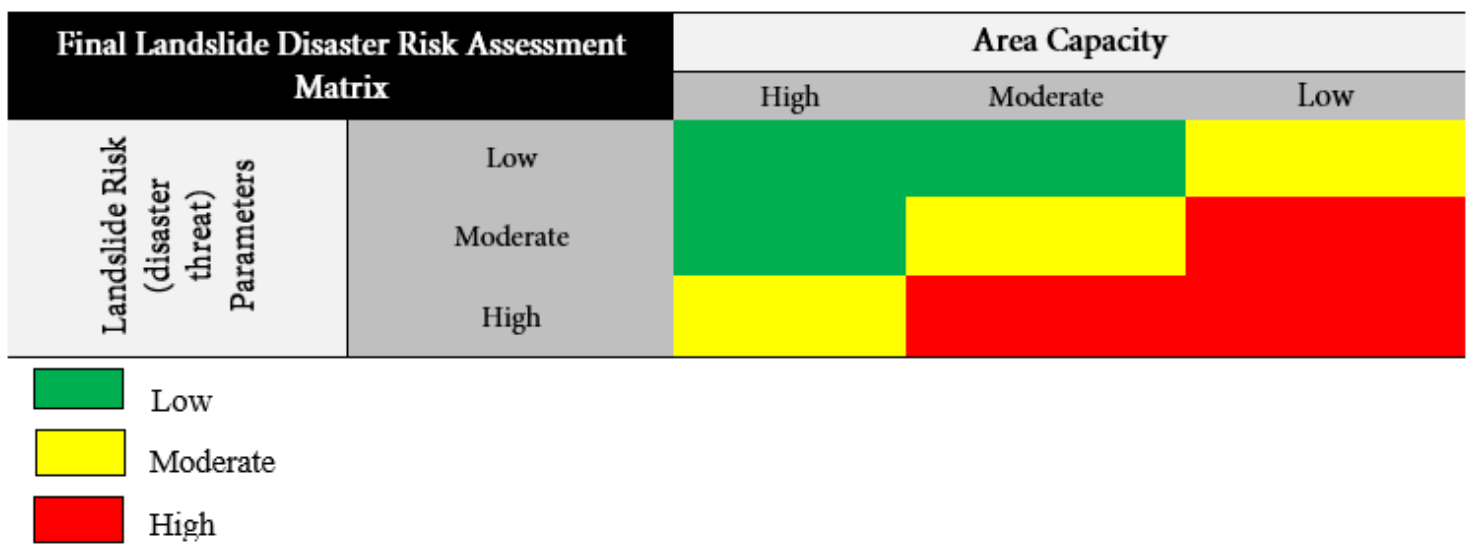


The preparation and results of the matrix were in accordance with the disaster risk assessment stipulated in the Regulation of the Head of BNPB Number 02 the year 2012 concerning General Guidelines for Disaster Risk Assessment. The values of each of the factors, either high or low, were used in determining and assessing the landslides risk and may influence the outcome of the landslide risk assessment. There was an interdependency between one factor and the others and all factors may influence each other so that if one factor was missing or was not included, the disaster risk assessment of the landslide hazard could not be carried out. A disaster risk assessment could be used as the basis to reduce the landslide risk, strategic plans, dissemination of disaster mitigation, policy-making in land use direction, disaster management, as well as landslide risk management and prevention to reduce the possibility of losses.

\section{Conclusion}

Pandansari Village, Ngantang District, has different landslide risks in each of the land ownership. The landslide risks were divided into three levels/categories, namely high risk with a total area of 1118.77 ha, moderate risk with a total area of 774.49 , and low risk with a total area of 557.71 ha. Perhutani's land was the land with the broadest area with a high level of landslide hazards. The hamlet with the most extensive area with a moderate level of landslide hazards was Sedawun Hamlet, while the hamlet with the most extensive area of low-level landslide disaster risk was Sambirejo. The high-risk level landslide was affected by high-level landslide hazard factors, low vulnerability ${ }_{2}$ and low capacity factors so that the risk level of landslides was high. The moderate level of landslide risk was influenced by high-level landslide hazard factors, moderate level of vulnerability, and high capacity factors. Finally, the low level of landslide risk was influenced by a low and moderate level of landslide disaster, a moderate vulnerability but a high level of regional capacity so that the risk level was low. Volcanic areas tend to have a higher level of risk when compared to the region located in inactive mountains. This is due to the physical condition of an active volcano that always has a source of eruption material as avalanche material as well as the socio-economic situation. According to the above result, we can conclude that landslide disasters influence not only by physical factors but also by the social aspect. Concerning landslide disaster management, this risk analysis gives comprehensive input reaching good management practice in Pandansari village.

\section{Acknowledgment}

The authors are grateful to RISTEKDIKTI (Directorate General of Higher Education, Ministry of National Education of Republic Indonesia), who supported this research activity through a PUPT Research Scheme

\section{References}

Abidin, HA (2007). Volcano Deformation Monitoring in Indonesia: Status, Limitations, and Prospects. International Association of Geodesy Symposia Volume. 130: 790-798.

Ahdi, Didi (2015). Perencanaan Penanggulangan Bencana Melalui Pendekatan Manajemen Risiko. Program Magister Ilmu Admiistrasi Publik, Universitas Brawijaya ISSN 2088-7469 (Paper) ISSN 2407-6864 (Online). Vol. 5, No. 1, 2015.

Ayala, Irasema Alcantara (2001). Geomorphology, Natural Hazards, Vulnerability And Prevention Of Natural Disasters In
Developing Countries. Department of Civil and Environmental Engineering, Massachusetts Institute of Technology, Room 1330, 77 Massachusetts Avenue, Cambridge MA 02139-4307, www.elsevier.com/locate/geomorph.

Bachri, S., Shresta, R.P., Yulianto, F., Sumarmi, Utomo, K. S. B., Aldianto, Y. E. (2021). Mapping Landform and Landslide Susceptibility Using Remote Sensing, GIS, and Field Observation in the Southern Cross Road, Malang Regency, East Java, Indonesia. Geosciences, 11, 4. Retrieved August 28, 2021, from: https://www.mdpi.com/2076-3263/11/1/4

Bachri, S., et al (2019). Landslide Susceptibility Mapping (LSM) in Kelud Volcano Using Spatial Multi-Criteria Evaluation (PDF Download Available). Retrieved August 28, 2021, from: https:// iopscience.iop.org/article/10.1088/1755-1315/273/1/012014

Bachri, S., \& P. Shresta, R. (n.d.) (2017). Landslide hazard assessment using analytic hierarchy processing (AHP) and geographic information system in Kaligesing mountain area of Central Java Province Indonesia (PDF Download Available). Retrieved June13,2017, from: https://www.researchgate.net/ publication/303582492_Landslide_hazard_assessment_using_a nalytic_hierarchy_processing_AHP_and_geographic_informati on_system_in_Kaligesing_mountain_area_of_Central_Java_Pr ovince_Indonesia.

Badan Nasional Penanggulangan Bencana (2012). Panduan Penilaian Kapasitas Daerah Dalam Penanggulangan Bencana. Peraturan Kepala Badan Nasional Penanggulangan Bencana No. 3 Tahun 2012. BNPB. Jakarta.

Badan Nasional Penanggulangan Bencana (2012). Pedoman Umum Pengkajian Risiko Bencana. Peraturan Kepala Badan Nasional Penanggulangan Bencana No. 2 Tahun 2012. BNPB. Jakarta.

Balai Penelitian Tanaman Aneka Kacang dan Umbi, Kementerian Pertanian (2014). Berita: Desa Pandansari Paling Parah Terkena Dampak Erupsi Gunung Kelud di Malang. BALITKABI. Malang

Bankoff, Greg., Georg frerks, and Dorothea hilhorst (2004). Mapping Vulnerability, Disasters, Development, And People. DOI: $10.4324 / 9781849771924$.

Blaikie, P., Cannon, T., Davis. I and Wisner, B (1994). At Risk: Natural Hazards, People's Vulnerability And Disasters. Routledge, London.

Blake, D., and GNS Science (N.Z.) (2015). The 2014 Eruption of Kelud Volcano, Indonesia: Impacts on Infrastructure, Utilities, Agriculture and Health.

Calvi, G.M., Pinho, R., Magenes, G., Bommer, J.J., Restrepo-Vélez, L.F. and Crowley, H (2006). Development of Seismic Vulnerability Assessment Methodologies Over The Past 30 Years. ISET Journal of Earthquake Technology, Paper No. 472, 43 (3), 75-104.

Catani, F., Casagli, N., Ermini, L., Righini, and G., Menduni, G (2005). Landslide Hazard And Risk Mapping At Catchment Scale In The Arno River Basin. Landslides 2 (4), 329-343.

Chiu, Jessica Ka Yi (2015). Landslide Risk Management Perceptions In Territories Comparative Case Studies Of Hong Kong And Norway. Master's Thesis, Department of Geosciences.

Department of Geosciences. Faculty of Mathematics and Natural Sciences. The University of Oslo.

Corominas, J.,et,al (2013). Recommendations For The Quantitative Analysis Of Landslide Risk. Bull Eng Geol Environ. DOI 10.1007/s10064-013-0538-8.

Ercanoglu, M., Gokceoglu, C (2002). Assessment Of Landslide Susceptibility For A Landslide-Prone Area (North Of Yenice, NW Turkye) By Fuzzy Approach. Environmental Geology 41, 720-730.

Ermini, L., Catani, F, and Casagli, N (2005). Artificial Neural Networks Applied To Landslide Susceptibility Assessment. Geomorphology 66 (1-4), 327-343.

Fell, R., Corominas, J., Bonnard, C., Cascini, L., Leroi, E, and Savage, W.Z (2008). Guidelines For Landslide Susceptibility, Hazard And Risk Zoning For Land Use Planning. Engineering Geology, 102, 8598 112-131. 
Guzzetti, F., and Cardinali, M (1990). Landslide inventory map of the Umbria region, Central Italy. Proceedings ALPS, 90, 273284.

Hidayati, Deny (2008). Kesiapsiagaan Masyarakat Paradigma Baru Pengelolaan Bencana Alam Di Indonesia. Jurnal Kependudukan Indonesia. III (1):69-84.

Highland, L.M. and Bobrowsky, P (2008). The landslide handbook-A guide to understanding landslides. Reston, Virginia, U.S. Geological Survey Circular 1325. 129 p.

Huppert, H. E, and W. B. Dade (1998), Natural Disaster: Explosive Volcanic Eruptions and Gigantic Landslide. Theoretical and Computational Fluid Dynamics, 10, 201212.

Isyanto, S Bekti (2013). Penggunaan Media Komunikasi Tradisional Sebagai Upaya Pengurangan Jatuhnya Korban Akibat Bencana Alam. Jurusan Ilmu Komunikasi FISIP Universitas Jenderal Soedirman Purwokerto. Jurnal Ilmu Komunikasi, Volume 2, Nomor 2, September 2013, hlm. 1-82.

Karnawati, D (2001). Bencana Alam Gerakan Tanah Indonesia Tahun 2000 (Evaluasi dan Rekomendasi). Jurusan Teknik Geologi. Fakultas Teknik Universitas Gadjah Mada. Yogyakarta.

Karnawati, D (2003). Manajemen Bencana Gerakan Tanah. Diktat Kuliah. Yogyakarta : Jurusan Teknik Geologi, Universitas Gadjah Mada.

Keys, J.R (1996). Secondary alpine hazards induced by the 19951996 eruption of Ruapehu volcano, New Zealand. In Proceedings of the International Snow Science Workshop. Canadian Avalanche Association: Banff (pp.279-284). Accessed from: http://arc.lib.montana.edu/sonw-science/objective/issw1996-279-284.pdf.

Krueger, Richard A (1988). FOCUS GROUPS: A Practical Guide for Applied Research. SAGE Publications. California

Lestari, Evi Dwi., Junun Sartohadi, Galih Aries Swastanto, and Hariyono Roestam (2014). Kondisi Masyarakat dan Pemerintah pada Masa Krisis Erupsi Gunungapi Kelud 2014. Bunga Rampai Penelitian-Pengelolaan Bencana Kegunungapian Kelud Pada Periode Krisis Erupsi 2014. Yogyakarta.

Maskey, A (1993). Vulnerability Accumulation In Peripheral Regions In Latin America: The Challenge For Disaster Prevention And Management. In: Merriman, P.A., Browitt, C.W.A. (Eds.), Natural Disasters: Protecting Vulnerable Communities. Thomas Telford, London, pp. 461-472.

Mei, Estuning Tyas Wulan., Franck Lavigne, Adrien Picquout, Edouard de Bélizal, Daniel Brunstein, Delphine Grancher, Junun Sartohadi, Noer Cholik, and Céline Vidal (2013). Lessons learned from the 2010 evacuations at Merapi volcano. VOLGEO-05104; No of Pages 18. Received 2 March 2012. Accepted 14 March 2013.

Mondal, Sujit., Arjun Mukherjee and Ramakrishna Maiti (2012). Application of a RS- and GIS-based semi-quantitative approach (analytical hierarchy process - AHP) in landslide hazard risk assessment of the Shivkhola Watershed, Darjiling Himalaya. Pages 203-220 https://doi.org/10.1080/17499518.2012.719392.

Nadim, F., and Suzanne Lacasse (2009). Landslide Risk Assessment and Mitigation Strategy. ICG/NGI (International Centre for Geohazards/Norwegian Geotechnical Institute), Norway.

Nadim, F., Kjekstad, O., Peduzzi, P., Herold, C. and Jaedicke, C (2006). "Global landslide and avalanche hotspots". Landslides, Vol. 3, No. 2, pp. 159-174.

Nurdiansyah, Farizki Dwitri (2017). Analisis Metode FuzzyAnalytical Hierarchy Process (FAHP) Untuk Pemetaan Kerawanan Tanah Longsor Di Kawasan Gunung Api Kelud, Jawa Timur. Malang: FIS Universitas Negeri Malang (Skripsi).

Paripurno, E.T (2001). Manajemen Berbasis Komunitas : Seperti apa?. Bahan Diskusi pada Lokalatih Bencana Kulonprogo. Kulonprogo, 30-31 Januari 2001.

Pelling, M (2003). The Vulnerability of Cities: Natural Disaster and Social Resilience, Earthscan, London.

Rahman, Amni Zarkasyi (2015). Kajian Mitigasi Bencana Tanah Longsor Di Kabupaten Banjarnegara. Jurnal Manajemen Dan Kebijakan Publik. Vol. 1, No. 1, Oktober 2015. ISSN 2460-9714.
Saputra, I Wayan Gede Eka (2015). Analisis Risiko Bencana Tanah Longsor Di Kecamatan Sukasada, Kabupaten Buleleng Program Magister. Program Studi Ilmu Lingkungan Program Pascasarjana Universitas Udayana. Denpasar. Bali.

Sudibyakto (2011). Manajemen Bencana di Indonesia ke Mana?. Yogyakarta: Gadjah Mada University Press.

Surono (2003). Potensi Bencana Geologi di Kabupaten Garut. Prosiding Semiloka Mitigasi Bencana Longsor di Kabupaten Garut. Pemerintah Kabupaten Garut.

UN-ISDR (2004). Terminology of Disaster Risk Reduction. United Nation, International Strategy for Disaster Reduction, Geneva, Switzerland.

http://www.unisdr.org/eng/library/lib-terminologyeng\% 20home.htm

UNPD (2004). Reducing Disaster Risk. A Challenge For Development. A global report. UNPD, New York, p 161.

Van Westen C.J., Alkema, D., Damen, M.C.J., Kerle, K., and Kingma, N.C (2011). Multi-hazard risk assessment: Distance Education Course Guide Book. United Nations University ITC School on Disaster Geoinformation Management. 371 p.

Van Westen C.J (2010). Remote Sensing and GIS for Natural Hazards Assessment and Disaster Risk Management. Faculty of Geo-Information Science and Earth Observation (ITC), University of Twente Hengelosestraat 907500 AA Enschede, The Netherlands.

Van Westen, C.J., Castellanos Abella, E.A. and Sekhar, L.K (2008). Spatial Data For Landslide Susceptibility, Hazards And Vulnerability Assessment : an overview. In: Engineering geology, 102 (34).

Wardhana, Garri Martha Kusuma, Febrian Maritimo, Edwin Maulana, Ali Ammarullah (2014). Pemetaan Daerah Rawan Jatuhan Material Piroklastik: Kasus Erupsi Gunungapi Kelud 2014. Bunga Rampai Penelitian-Pengelolaan Bencana Kegunungapian Kelud Pada Periode Krisis Erupsi 2014. Yogyakarta. 